\section{Cerebral blood flow velocity patterns during cardiac surgery utilizing profound hypothermia with low- flow cardiopulmonary bypass or circulatory arrest in neonates and infants}

Frederick A. Burrows MD FRCPC, Bruno Bissonnette MD FRCPC
To examine the effects of low-flow cardiopulmonary bypass (CPB) and circulatory arrest (PHCA) on cerebral pressure-flow velocity relationships, we studied 32 patients $(<9$ mo of age) undergoing corrective cardiac procedures. Pressure-flow velocity relationships were studied during profound hypothermia (nasopharyngeal temperature $<20^{\circ} \mathrm{C}$ ). Cerebral blood-flow velocity (CBFV) was measured in the middle cerebral artery using transcranial Doppler sonography. The anterior fontanel pressure (AFP) was measured using an intracranial pressure monitor. Cerebral perfusion pressure (CPP) was calculated $(\mathrm{mmHg})$ as mean arterial pressure (MAP) minus AFP. Nasopharyngeal temperature, $\mathrm{PaCO}_{2}$ and haematocrit were controlled during

\section{Key words}

ANAESTHESIA: paediatric;

BRAIN: blood flow;

MEASUREMENT TECHNIQUES: ultrasound;

SURGERY: cardiac;

TEMPERATURE: hypothermia.

From the Departments of Anaesthesia and Paediatrics (Cardiology) and The Research Institute, The Hospital for Sick Children, Toronto, Ontario, Canada. Presented in part at the Annual Meeting of the International Anesthesia Research Society, March 1992, San Francisco, California.

Address correspondence to: Dr. Frederick A. Burrows, Department of Anaesthesia, The Hospital for Sick Children, 555 University Avenue, Toronto, Ontario, M5G 1X8. After January 8, 1993: Department of Anesthesia, The Children's Hospital, 300 Longwood Avenue, Boston, Massachusetts, USA 02115.

Accepted for publication 16th December, 1992. the study period. Alpha-stat acid-base management was employed. The CBFV measurements were made continuously over a range of $C P P$ as pump flow $(\dot{Q})$ was decreased to low-flow or to circulatory arrest and again during the subsequent increase in $\dot{Q}$ and $C P P$ to normal. $A s \dot{Q}$ and $C P P$ were increased after a period of low-flow $C P B$ during which period detectable $C B F V$ was present, the $C B F V$ was greater at any given $C P P$ than prior to the low-flow state $(P<0.05)$. However, after $P H C A$ a higher CPP $(P<0.05)$ was necessary to re-establish detectable $C B F V$ and at any given $C P P$ the $C B F V$ was less than prior to $P H C A(P<0.05)$. Seventeen patients underwent low-flow CPB during which CBFV became non-detectable (7) $\left.\pm 1 \mathrm{~cm} \cdot \mathrm{sec}^{-1}\right)$. In 12 of these patients the pattern of recovery of $C B F V$ was the same as that observed after low-flow CPB whereas the remaining five (29\%) demonstrated a pattern of recovery identical to the ones recorded after PHCA. We conclude that afier PHCA a higher CPP is necessary to re-establish and maintain detectable CBFV. Furthermore, during low-flow $C P B$, patients where $C B F V$ becomes non-detectable and show a pattern of $C B F V$ recovery similar to $P H C A$, cessation of cerebral perfusion must be considered.

Pour évaluer les effets de la circulation extracorporelle (CEC) à bas débit et de l'arrêt circulatoire sur la relation entre la vélocité et le débit sanguin, nous avons étudié 32 patients de moins de neuf mois soumis à des interventions cardiaques pour correction de malformations congénitales. Cette étude été réalisée sous lhypothermie profonde (température nasale $<20^{\circ} \mathrm{C}$ ). La vélocité du débit sanguin cérébral (VDSC) a été mesurée dans l'artère cérébrale moyenne au moyen de lultrasonographie Döppler. La pression de la fontanelle antérieure (PFA) a été évaluée à l'aide d'un moniteur de pression intra- 
crânienne. La pression de perfusion cérébrale $(P P C)$ a été calculée en $\mathrm{mmHg}$ en soustrayant la PFA de la pression artérielle moyenne (PAM). La température nasopharyngée, la $\mathrm{PaCO}_{2}$ et l'hématocrite ont été contrôlés pendant la période d'étude. Le système alpha-stat a été utilisé pour les gaz artériels (mesurés à $37^{\circ} \mathrm{C}$, non corrigés pour la température corporelle). Les mesures de VDSC ont été réalisées continuellement sur une gamme étendue de PPC alors que le débit de pompe $(\dot{Q})$ était diminué jusqu'à l'arrêt circulatoire. Ces mesures ont été répétées pendant l'augmentation subséquente de $\dot{Q}$ et de la $P P C$ jusqu'au retour à la normale. Alors que $\dot{Q}$ et la PPC étaient augmentés après une période de $C B C$ à bas débit au cours de laquelle la VDSC était encore détectable, celle-ci a été plus élevée pour une PPC donnée qu'avant la période de bas débit $(P<0,05)$. Cependant, après arrêt circulatoire, une PPC plus élevée $(P<0,05)$ a été nécessaire pour rétablir une VDSC détectable; pour une PPC donnée, le VDSC a toujours été plus basse quiavant l'arrêt circulatoire $(P<0,05)$. Dix-sept patients ont été perfusés sous CEC à bas débit pendant laquelle on n'a pu détecter de VDSC (seuil de détectabilité $>7 \pm$ $1 \mathrm{~cm} \cdot \mathrm{sec}^{-1}$ ). Chez 12 de ces patients, le pattern de la récupération de la VDSC était le même que celui qui est observé après des CEC à bas débits, alors que les cinq autres (29\%) montraient un pattern de récupération identique que celui qu'on retrouvait après un arrêt circulatoire. Nous concluons qu'après arrêt circulatoire, une PPC plus élevée est nécessaire pour rétablir et maintenir une VDSC détectable. De plus, durant la CEC à bas débit, les malades où la VDSC devient indétectable et qui montrent un pattern de récupération semblable à l'arrêt circulatoire, un arrêt de la perfusion cérébrale doit être mis en cause.

Profound hypothermia with continuous low-flow cardiopulmonary bypass (low-flow CPB) has been suggested to be superior to profound hypothermic circulatory arrest (PHCA) in preventing neurological damage during the repair of complex congenital cardiac defects (CHD). ${ }^{1,2}$ During low-flow CPB it has been demonstrated that cerebral perfusion pressure (CPP), cerebral blood flow (CBF) and cerebral blood flow velocity (CBFV) are less than with normal pump flows. ${ }^{3,4}$

Our hypothesis is that during the institution of lowflow CPB when the mean arterial pressure (MAP) and subsequently CPP decrease, the transmural pressure necessary to maintain patency in the cerebral resistance vessels is less than during increasing CPP which accompanies the return to normal CPB flow rates (Q). Such a finding would support the hysteresis behavior of elastic tissues. ${ }^{5-7}$ We also hypothesized that when CPP decreases below a critical pressure, the cerebral vessels close and the pressure to re-establish flow would be greater than that at which the vessels close.
We used a transcranial Doppler to investigate the effects of variations in $\dot{Q}$ on the cerebral blood flow velocity to cerebral perfusion pressure relationship. Transcranial Doppler sonography allows us to monitor, noninvasively, the cerebral blood-flow velocity during repair of congenital heart defects requiring profound hypothermia with a reduction in cardiopulmonary bypass flow rates to lowflow states or with circulatory arrest. The use of CBFV as an index of cerebral perfusion has been established previously. $4,8,9$

During low-flow CPB, CPP may be greatly reduced. ${ }^{10,11}$ The behaviour of cerebral vessels, specifically the presence of critical closing and opening pressures, ${ }^{11}$ and the presence of hysteresis, characteristic of elastic tissues, ${ }^{5-7}$ at such low CPP has not been investigated in vivo.

\section{Methods}

With approval from the Human Subject Review Committee at the Hospital for Sick Children, Toronto, Ontario, 32 patients ( 21 male) less than nine months of age admitted for surgical repair of congenital cardiac defects were studied.

Anaesthesia was induced and maintained with 50-100 $\mu \mathrm{g} \cdot \mathrm{kg}^{-1}$ fentanyl $i v$ and neuromuscular blockade was achieved with $0.15 \mathrm{mg} \cdot \mathrm{kg}^{-1}$ pancuronium iv. After nasotracheal intubation, the lungs were ventilated with intermittent positive pressure with an air/oxygen mixture $\left(\mathrm{FIO}_{2}\right.$ of $\left.0.7-1.0\right)$. Supplemental doses of fentanyl and pancuronium were administered as necessary. An arterial catheter was inserted for continuous measurement of systemic arterial pressure and for intermittent blood sampling. A central venous catheter was inserted percutaneously into the superior vena cava through the external or internal jugular vein to measure the central venous pressure (CVP). Intracranial pressure (ICP) was estimated using a calibrated Ladd intracranial pressure monitor (Ladd Research Industries, Burlington, Vt.), which measured anterior fontanel pressure (AFP). ${ }^{12}$ The AFP was continuously recorded on a single-channel recorder. Rectal, oesophageal and nasopharyngeal temperatures were monitored. No cerebral vasoactive agents were administered.

Cerebral blood flow velocity was measured noninvasively by transcranial Doppler sonography using the Transpect TCD (Medasonics, Fremont, Calif.). The transducer probe was placed over the temporal window to display the M1 segment of the middle cerebral artery (MCA) flow. To ensure a reproducible window, the MCA signal was accompanied in every case with retrograde anterior cerebral flow (Al segment). A range-gated, pulsed-wave Doppler probe (area $=1.5 \mathrm{~cm}^{2}$ ) with a frequency of $2 \mathrm{MHz}$, emitting power of $100 \mathrm{~mW}$, resolution 
of $3 \mathrm{~cm} \cdot \mathrm{sec}^{-1}$, and depth of $2.5-3.5 \mathrm{~cm}$ was used. The frequency spectrum of Doppler signals, displayed on a frequency analyzer in real time was stored, digitized and analyzed at a later date. The mean velocities of the stored data were determined by computer analysis of the area of the Doppler frequency tracing.

Nonpulsatile CPB was established with a standard roller pump (Cobe Canada Ltd., Scarborough, Ont.) and a 0.8 or $1.6 \mathrm{~m}^{2}$ Capiox hollow fibre membrane oxygenator (Terumo, Tokyo, Japan). The CPB circuit was primed with packed red blood cells, 5\% albumin and Plasmalyte (Travenol, Mississauga, Ont.) solution plus 1 $\mathrm{g} \cdot \mathrm{kg}^{-1}$ mannitol to maintain a haematocrit of $25-30 \%$ during CPB. The normal range of $\mathrm{CPB}$ flows was considered as $2.4-3.2 \mathrm{~L} \cdot \mathrm{min}^{-1} \cdot \mathrm{m}^{-2}$ (approximately 100 $\left.150 \mathrm{ml} \cdot \mathrm{kg}^{-1} \cdot \mathrm{min}^{-1}\right)$. Patients were cooled at a rate of $1-3^{\circ} \mathrm{C} \cdot \mathrm{min}^{-1}$, nasopharyngeal.

Arterial blood gases were analyzed using alpha-stat method of acid-base management which consisted of analyzing the blood at $37^{\circ} \mathrm{C}$ and not correcting for body temperature. The $\mathrm{PaCO}_{2}$ was maintained between 30 and $40 \mathrm{mmHg}$, and the $\mathrm{pH}$ between 7.35 and 7.45. Arterial blood gas determinations were performed using a Nova Stat Profile 5 blood-gas analyzer (Nova Biomedical, Waltham, Mass.). During CPB, arterial acid-base status was continuously monitored with a CDI 300 monitoring system (Cardiovascular Devices, Inc., Irvine, Calif.).

The decision as to the use of normal or low-flow CPB, or PHCA was based on the surgical requirements of the corrective procedure.

Throughout the study, AFP, MAP, CVP, CBFV, and nasopharyngeal, oesophageal and rectal temperatures were measured and reconded continuously. Arterial blood gas and haematocrit analysis were performed and the results recorded every $15 \mathrm{~min}$.

For the purposes of this study low-flow CPB was defined as a $\dot{Q}$ of less than $1.2 \mathrm{~L} \cdot \mathrm{min}^{-1} \cdot \mathrm{m}^{-2}$ (approximately $50 \mathrm{ml} \cdot \mathrm{kg}^{-1} \cdot \mathrm{min}^{-1}$ ) at a NPT $<20^{\circ} \mathrm{C}$.

Cerebral blood flow velocity studies were performed during profound hypothermic (NPT $<20^{\circ} \mathrm{C}$ ) CPB. To determine the relationship between CBFV and CPP (calculated as MAP-AFP), continuous measurements were made as $\dot{Q}$ was first decreased and then increased according to the surgical requirements. This served to modify MAP and subsequently CPP. In five patients (Group A) low-flow CPB was not utilized but CPP was altered by changes in $Q$ within the normal range. In five patients (Group B) CPP was reduced by the requirement for lowflow $C P B$ such that $C B F V$ was maintained just above the threshold sensitivity of the TCD $\left(3-4 \mathrm{~cm} \cdot \mathrm{s}^{-1}\right)$. Five patients underwent PHCA (Group C). In 17 patients (Group D) the CPP was reduced sufficiently by the requirement for low-flow CPB such that CBFV became undetectable; the CBFV became detectable again when $\dot{Q}$ (and subsequently CPP) was increased at the end of the necessary low-flow period.

All patients underwent routine preoperative and postoperative clinical neurological evaluation. Neurological status was assessed by examination of cranial nerves, motor and sensory systems, and cerebellar function.

\section{Data analysis}

Intergroup demographic data were compared using oneway ANOVA and the Tukey multiple range test as indicated.

The CPP was calculated as the difference between the MAP and the AFP. Cerebral blood flow velocity was plotted (interpolated) against decreasing CPP until CBFV became undetectable or until the lowest CBFV was reached and then against increasing CPP. Student's paired $t$ test was used to compare the cerebral perfusion pressures at which CBFV became non-detectable with those at which it became detectable again.

The change in CBFV for each patient per unit change in CPP induced by alterations in $\mathbf{Q}$ was calculated using linear regression analysis and the slope of the line of best fit reported as $\mathrm{dV} / \mathrm{dP}\left(\mathrm{cm} \cdot \mathrm{sec}^{-1} \cdot \mathrm{mmHg}^{-1}\right)$. The $\mathrm{dV} / \mathrm{dP}$ during decreasing $\mathrm{Q}$ was compared with that during increasing $\mathbf{Q}$ using Student's paired $t$ test.

The time temperature products $(\mathrm{T} \times \mathrm{C}),{ }^{13,14}$ used as an index of potential ischaemic insult, were calculated for the three groups and compared using one-way ANOVA and the Tukey multiple range test. When lowflow $\mathrm{CPB}$ was used, $\mathrm{T} \times \mathrm{C}$ for each patient was calculated as the product of the duration of the low-flow period (minutes) and the NPT $\left({ }^{\circ} \mathrm{C}\right)$ at the end of the low-flow period. In patients who underwent PHCA, T $X \mathrm{C}$ was calculated as the product of the duration of the circulatory arrest period (minutes) and the NPT $\left({ }^{\circ} \mathrm{C}\right)$ at the end of circulatory arrest.

Statistical significance was accepted as $P<0.05$. Data are expressed as mean \pm standard deviation (SD).

\section{Results}

The demographic data are presented in Table I. The patients in Group B (low-flow CPB) were older and of greater weight than those in Group C (PHCA) $(P<$ 0.05 ) but there were no differences in age or weight among the other groups. The Group C (PHCA) patients demonstrated a higher temperature at the end of the PHCA period and a greater $\mathrm{T} \times \mathrm{C}$ product when compared with the temperature at the end of the low-flow $\mathrm{CPB}$ period and the $\mathrm{T} \times \mathrm{C}$ product of the patients having undergone low-flow CPB (Groups B and D). The duration of low-flow $\mathrm{CPB}$ was also less than the duration of the PHCA period $(P<0.05)$. 
TABLE I Demographic data

\begin{tabular}{|c|c|c|c|c|c|}
\hline Diagnosis & $\begin{array}{l}\text { Age } \\
\text { (days) }\end{array}$ & $\begin{array}{l}\text { Weight } \\
(\mathrm{kg})\end{array}$ & $\begin{array}{l}\text { Temperature } \\
\left({ }^{\circ} \mathrm{C}\right)\end{array}$ & $\begin{array}{l}\text { Duration } \\
\text { (min) }\end{array}$ & $T \times C$ \\
\hline \multicolumn{6}{|c|}{ Group A patients (normal pump flow range) } \\
\hline TGA & 102 & 5.74 & 19.7 & & \\
\hline VSD & 57 & 3.30 & 19.5 & & \\
\hline TGA & 13 & 4.60 & 19.5 & & \\
\hline AVSD & 59 & 3.43 & 19.9 & & \\
\hline AVSD & 119 & 4.82 & 19.8 & & \\
\hline $\begin{array}{l}\text { Mean } \\
( \pm S D)\end{array}$ & $\begin{array}{l}70^{*} \\
( \pm 42)\end{array}$ & $\begin{array}{l}4.38 \\
( \pm 0.46)\end{array}$ & $\begin{array}{l}19.7 \\
( \pm 0.2)\end{array}$ & & \\
\hline \multicolumn{6}{|c|}{ Group B patients (low-flow CPB; detectable perfusion present) } \\
\hline TGA & 57 & 3.72 & 19.9 & 9 & 179.1 \\
\hline DORV & 43 & 3.43 & 17.4 & 28 & 487.2 \\
\hline VSD & 131 & 5.15 & 19.3 & 14 & 270.2 \\
\hline VSD & 189 & 5.43 & 20.1 & 12 & 241.2 \\
\hline TGA & 83 & 4.82 & 19.7 & 22 & 424.6 \\
\hline $\begin{array}{l}\text { Mean } \\
( \pm S D)\end{array}$ & $\begin{array}{l}101 \\
( \pm 60)\end{array}$ & $\begin{array}{l}4.50^{*} \\
( \pm 0.89)\end{array}$ & $\begin{array}{l}19.3 \\
( \pm 1.1)\end{array}$ & $\begin{array}{l}17 \\
( \pm 8)\end{array}$ & $\begin{array}{l}320.5 \\
( \pm 129.8)\end{array}$ \\
\hline \multicolumn{6}{|c|}{ Group C patients (PHCA) } \\
\hline TAPVD & 4 & 3.20 & 21.2 & 34 & 720.8 \\
\hline VSD & 9 & 3.10 & 19.5 & 42 & 819.0 \\
\hline AVSD & 12 & 2.93 & 20.7 & 61 & 1323.7 \\
\hline TGA & 7 & 3.65 & 19.1 & 47 & 897.7 \\
\hline Truncus & 34 & 2.90 & 22.3 & 64 & 1427.2 \\
\hline $\begin{array}{l}\text { Mean } \\
( \pm S D)\end{array}$ & $\begin{array}{l}13 \\
( \pm 12)\end{array}$ & $\begin{array}{l}3.16 \\
( \pm 0.30)\end{array}$ & $\begin{array}{l}20.6 \S \\
( \pm 1.3)\end{array}$ & $\begin{array}{l}50 \dagger \\
( \pm 13)\end{array}$ & $\begin{array}{l}1037.7 \dagger \\
( \pm 316.8)\end{array}$ \\
\hline
\end{tabular}

Group $D^{\prime}$ patients (low-flow CPB; detectable perfusion absent)

\begin{tabular}{lcllcl} 
DORV & 132 & 5.02 & 19.5 & 34 & 663.0 \\
TGA & 96 & 5.10 & 19.3 & 7 & 135.1 \\
TGA & 11 & 4.42 & 18.2 & 12 & 218.4 \\
AVSD & 25 & 3.86 & 18.8 & 21 & 394.8 \\
Truncus & 4 & 2.98 & 19.1 & 16 & 305.6 \\
VSD & 9 & 3.41 & 17.9 & 15 & 268.5 \\
VSD & 63 & 4.30 & 18.3 & 11 & 201.3 \\
DORV & 38 & 3.69 & 19.5 & 22 & 429.0 \\
AVSD & 154 & 5.87 & 19.7 & 18 & 354.6 \\
TGA & 61 & 3.75 & 18.6 & 8 & 148.8 \\
VSD & 22 & 3.61 & 18.2 & 11 & 200.2 \\
TGA & 9 & 3.23 & 19.7 & 22 & 433.4 \\
Mean & 52 & 4.10 & 18.9 & 16 & 312.7 \\
( \pm SD) & $( \pm 51)$ & $( \pm 0.86)$ & $( \pm 0.7)$ & $( \pm 8)$ & $( \pm 151.9)$ \\
Group $D^{2}$ patients & $($ low-flow CPB; detectable perfusion absent) & & \\
TGA & 7 & 3.41 & 19.5 & 12 & 234 \\
TGA & 14 & 3.72 & 19.7 & 7 & 137.9 \\
VSD & 29 & 2.79 & 18.9 & 18 & 340.2 \\
AVSD & 62 & 4.07 & 19.2 & 26 & 499.2 \\
TGA & 12 & 3.90 & 18.4 & 9 & 165.6 \\
Mean & 25 & 3.58 & 19.1 & 14.4 & 275.4 \\
$( \pm S D)$ & $( \pm 22)$ & $( \pm 0.51)$ & $( \pm 0.5)$ & $( \pm 8)$ & $( \pm 147.5)$ \\
\hline
\end{tabular}

* $P<0.05$ compared with Group $C$ patients.

$\dagger P<0.05$ compared with all other groups.

$\S P<0.05$ compared with Groups $\mathrm{B}, \mathrm{D}^{1}$ and $\mathrm{D}^{2}$.

Abbreviations: VSD - ventricular septal defect; TGA - transposition of the great arteries; AVSD -

atrioventricular septal defect; DORV - double outlet right ventricle; TAPVD - total anomalous pulmonary

venous drainage; Truncus - truncus arteriosus; $\mathrm{T} \times \mathrm{C}$ - time temperature product. 


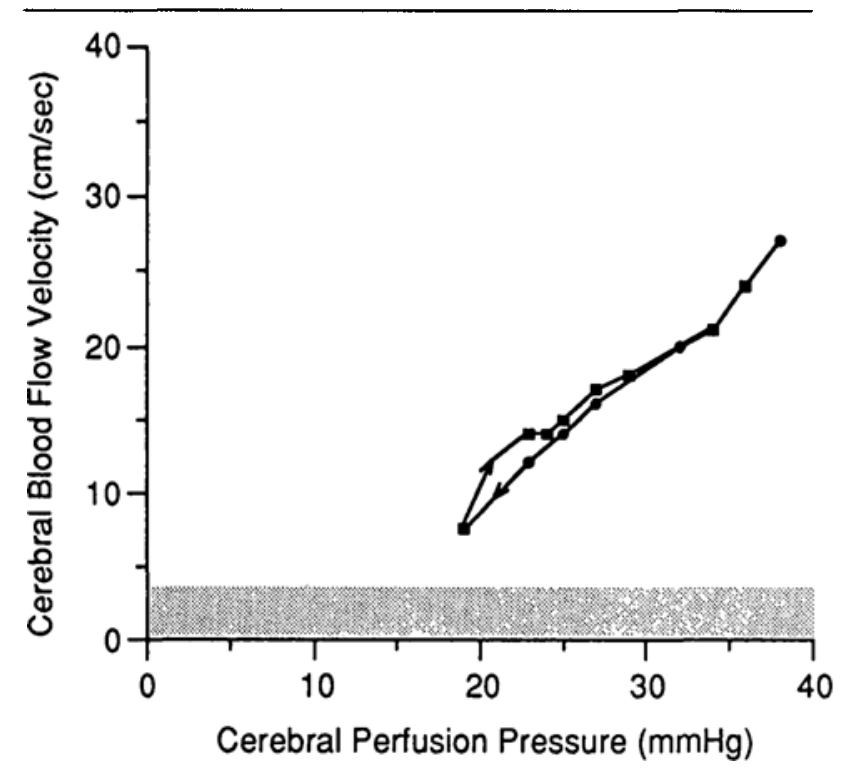

FIGURE 1 Interpolated values of cerebral blood flow velocity (CBFV) changes representing one patient during decreasing $(--)$ and increasing ( $-\square-$ ) cerebral perfusion pressure (CPP), induced by alterations in pump flow within the normal range. The slope (dV/ $\mathrm{dP})$ of the CBFV-to-CPP relationship during decreasing ( 0.95 $\left.\mathrm{cm} \cdot \mathrm{sec}^{-1} \cdot \mathrm{mmHg}^{-1}\right)$ and increasing $\left(0.86 \mathrm{~cm} \cdot \mathrm{sec}^{-1} \cdot \mathrm{mmHg}^{-1}\right)$ pump flow respectively were determined by linear regression analysis. There was no statistical difference between the $\mathrm{dV} / \mathrm{dP}(P=0.42)$ or the $y$ intercept $(P=0.29)$ of the lines. The shaded area represents the area below the threshold of resolution of the transcranial Doppler (3-4 $\mathrm{cm} \cdot \mathrm{sec}^{-1}$ ).

In the patients in Group A (control) the CBFV decreased and increased with the corresponding change in $\dot{\mathrm{Q}}$, MAP and subsequently CPP. All changes in $\dot{Q}$ were within the normal range $\left(2.4-3.21 \cdot \mathrm{min}^{-1} \cdot \mathrm{m}^{-2}\right)$ and there was no difference between $\mathrm{dV} / \mathrm{dP}$ during decreasing $\dot{Q}$ from with that during increasing $\dot{Q}$ (Figure 1, Table II).

In the Group B (low-flow) patients the CBFV decreased pari passu with the decrease in CPP induced by the induction of low-flow CPB (Figure 2, Table II). Cerebral perfusion pressure decreased to $13( \pm 2) \mathrm{mmHg}$ and $\mathrm{CBFV}$ decreased to $9( \pm 1) \mathrm{cm} \cdot \mathrm{sec}^{-1}$ but CBFV did not become undetectable in any patient in this group. With the termination of low-flow CPB and the return of $\dot{Q}$ to the normal range, CPP increased. Cerebral blood flow velocity increased but with a greater $\mathrm{dV} / \mathrm{dP}$ than during the decrease in CPP. Cerebral blood flow velocity returned to within $5 \%$ of pre-low-flow CPB values within $3.2( \pm 1.2) \mathrm{min}$ after the return of $\dot{Q}$ and CPP to within normal values.

In the patients in Group C (PHCA) the CBFV decreased linearly as $\dot{Q}$, and CPP decreased (Figure 2).

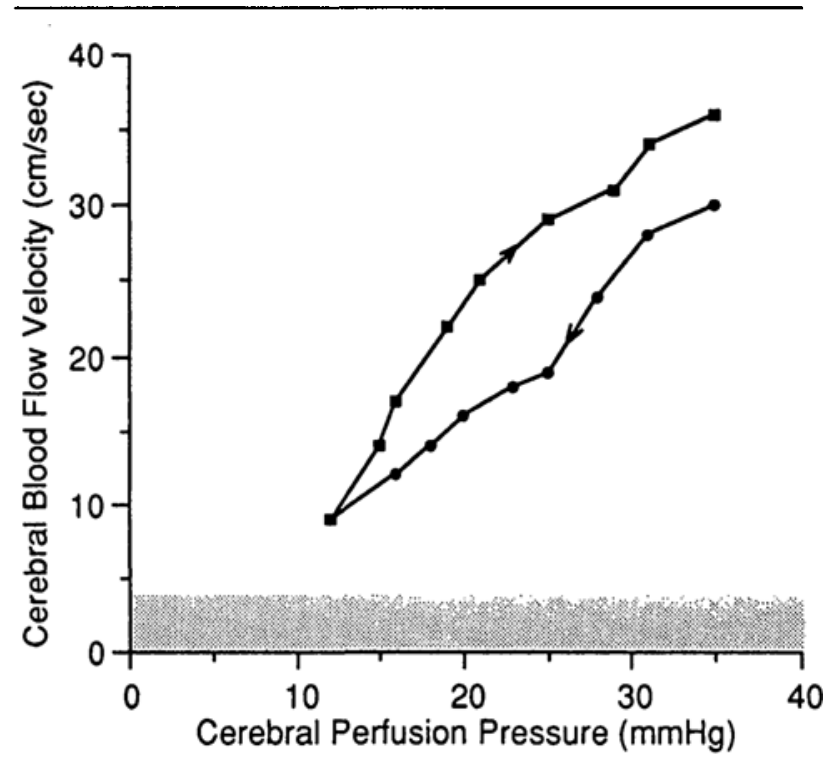

FIGURE 2 Interpolated values of cerebral blood flow velocity (CBFV) changes representing one patient during decreasing $(--)$ ) and increasing ( $-\square-$ ) cerebral perfusion pressure (CPP), induced by alterations in pump flow to establish low-flow cardiopulmonary bypass (CPB). The slope ( $\mathrm{dV} / \mathrm{dP})$ of the CBFV-to-CPP relationship during decreasing $\left(0.95 \mathrm{~cm} \cdot \mathrm{sec}^{-1} \cdot \mathrm{mmHg}^{-1}\right)$ and increasing $(1.15$ $\mathrm{cm} \cdot \mathrm{sec}^{-1} \cdot \mathrm{mmHg}^{-1}$ ) pump flow respectively were determined by linear regression analysis. The $\mathrm{dV} / \mathrm{dP}$ during decreasing pump flows and CPP was significantly less than during increasing pump flows and CPP after low-flow CPB $(P=0.04)$. The shaded area represents the area below the threshold of resolution of the transcranial Doppler (3-4 $\mathrm{cm} \cdot \mathrm{sec}^{-1}$ ).

Detectable CBFV disappeared at a mean CBFV of 9 $( \pm 2) \mathrm{cm} / \mathrm{sec}$ and CPP of $9( \pm 2) \mathrm{mmHg}$. The CBFV disappeared at a mean pump flow of $22( \pm 2) \%$ normal $\left(2.4 \mathrm{~L} \cdot \min ^{-1} \cdot \min ^{-2}\right)$ which was less than the other groups of patients $(P<0.05)$. In all cases the disappearance of detectable CBFV occurred before the establishment of PHCA. With the re-establishment of CPB after the period of PHCA (50 $\pm 13 \mathrm{~min})$ cerebral perfusion became detectable at a CPP of $13( \pm 2) \mathrm{mmHg}$ and a CBFV of $8( \pm 1) \mathrm{cm} \cdot \mathrm{sec}^{-1}$ which were different from that during the decrease in CPP. The $\mathrm{dV} / \mathrm{dP}$ of the CBFV was significantly less after PHCA. Cerebral blood flow velocity did not return to pre-PHCA values before termination of the CPB run $(P<0.05)$.

In the Group D patients (Table II) low-flow CPB was induced and CBFV decreased as CPP decreased. The CBFV disappeared in all patients, at a mean CPP of $9( \pm 1) \mathrm{mmHg}$, before reaching the resolution threshold of the TCD (3-4 cm $\left.\cdot \mathrm{sec}^{-1}\right) .{ }^{11}$ With the increase in the CPP as $\dot{Q}$ increased after the period of low-flow CPB, 12 patients (Group $D^{\prime}$ ) demonstrated a CBFV pattern which accorded with that demonstrated in the Group B 
TABLE II Cardiopulmonary bypass data

\begin{tabular}{|c|c|c|c|c|c|c|c|c|}
\hline Diagnosis & $\begin{array}{l}Q^{a} \\
\text { (\% of normal) }\end{array}$ & $\begin{array}{l}C P P^{a} \\
(m m H g)\end{array}$ & $\begin{array}{l}C B F V^{n} \\
\left(\mathrm{~cm} \cdot \sec ^{-1}\right)\end{array}$ & $\begin{array}{l}d V / d P^{e} \\
\left(\mathrm{~cm} \cdot \sec ^{-1} \cdot \mathrm{mmHg} g^{-1}\right)\end{array}$ & $\begin{array}{l}C P P^{b} \\
(m m H g)\end{array}$ & $\begin{array}{l}C B F V^{b} \\
\left(\mathrm{~cm} \cdot \sec ^{-1}\right)\end{array}$ & $\begin{array}{l}d V / d P^{f} \\
\left(\mathrm{~cm} \cdot \mathrm{sec}^{-1} \cdot \mathrm{mmHg^{-1 } )}\right.\end{array}$ & $P \S$ \\
\hline \multicolumn{9}{|c|}{ Group A patients (normal pump flow range) } \\
\hline TGA & & & & 0.95 & & & 0.86 & 0.42 \\
\hline VSD & & & & 1.41 & & & 1.19 & 0.36 \\
\hline TGA & & & & 1.36 & & & 1.44 & 0.08 \\
\hline AVSD & & & & 0.84 & & & 0.95 & 0.15 \\
\hline AVSD & & & & 0.82 & & & 0.79 & 0.26 \\
\hline $\begin{array}{l}\text { Mean } \\
( \pm S D)\end{array}$ & & & & $\begin{array}{l}1.08 \\
( \pm 0.29)\end{array}$ & & & $\begin{array}{l}1.05 \\
( \pm 0.27)\end{array}$ & \\
\hline
\end{tabular}

\begin{tabular}{|c|c|c|c|c|c|c|c|c|}
\hline Diagnosis & $\begin{array}{l}\dot{Q}^{c} \\
\text { (\% of normal) }\end{array}$ & $\begin{array}{l}C P P^{c} \\
(m m H g)\end{array}$ & $\begin{array}{l}C B F V^{c} \\
\left(\mathrm{~cm} \cdot \mathrm{sec}^{-1}\right)\end{array}$ & $\begin{array}{l}d V / d P^{e} \\
\left(\mathrm{~cm} \cdot \sec ^{-1} \cdot \mathrm{mmHg}^{-1}\right)\end{array}$ & $\begin{array}{l}C P P^{d} \\
(m m H g)\end{array}$ & $\begin{array}{l}C B F V^{d} \\
\left(\mathrm{~cm} \cdot \sec ^{-1}\right)\end{array}$ & $\begin{array}{l}d V / d P^{f} \\
\left(\mathrm{~cm} \cdot \mathrm{sec}^{-1} \cdot \mathrm{mmHg}^{-1}\right)\end{array}$ & $P \S$ \\
\hline \multicolumn{9}{|c|}{ Group B patients (low-flow CPB; detectable perfusion always present) } \\
\hline $\mathrm{TGA}$ & 28 & 11 & 8 & 0.96 & & & 1.15 & 0.04 \\
\hline DORV & 26 & 12 & 9 & 0.61 & & & 0.88 & 0.02 \\
\hline VSD & 31 & 14 & 10 & 0.49 & & & 0.77 & 0.01 \\
\hline VSD & 29 & 13 & 7 & 0.57 & & & 0.74 & 0.01 \\
\hline TGA & 33 & 15 & 9 & 0.38 & & & 0.59 & 0.03 \\
\hline $\begin{array}{l}\text { Mean } \\
( \pm S D)\end{array}$ & $\begin{array}{l}29 \\
( \pm 3)\end{array}$ & $\begin{array}{l}13 \\
( \pm 2)\end{array}$ & $\begin{array}{l}9 \\
( \pm 1)\end{array}$ & $\begin{array}{l}0.60 \\
( \pm 0.22)\end{array}$ & & & $\begin{array}{l}0.83 \ddagger \\
( \pm 0.21)\end{array}$ & \\
\hline
\end{tabular}

\begin{tabular}{|c|c|c|c|c|c|c|c|c|}
\hline Diagnosis & $\begin{array}{l}\dot{Q}^{a} \\
(\% \text { of normal) }\end{array}$ & $\begin{array}{l}C P P^{a} \\
(m m H g)\end{array}$ & $\begin{array}{l}C B F V^{n} \\
\left(\mathrm{~cm} \cdot \sec ^{-1}\right)\end{array}$ & $\begin{array}{l}d V / d P^{e} \\
\left(\mathrm{~cm} \cdot \sec ^{-1} \cdot \mathrm{mmHg}^{-1}\right)\end{array}$ & $\begin{array}{l}C P P^{b} \\
(m m H g)\end{array}$ & $\begin{array}{l}C B F V^{b} \\
\left(\mathrm{~cm} \cdot \sec ^{-1}\right)\end{array}$ & $\begin{array}{l}d V / d P^{f} \\
\left(\mathrm{~cm} \cdot \mathrm{sec}^{-1} \cdot \mathrm{mmHg}^{-1}\right)\end{array}$ & $P \S$ \\
\hline \multicolumn{9}{|c|}{ Group C patients (PHCA) } \\
\hline TAPVD & 23 & 9 & 8 & 0.92 & 13 & 9 & 0.57 & 0.03 \\
\hline VSD & 24 & 11 & 7 & 0.98 & 14 & 9 & 0.71 & 0.02 \\
\hline AVSD & 21 & 10 & 12 & 0.61 & 16 & 8 & 0.34 & 0.01 \\
\hline TGA & 19 & 7 & 9 & 1.01 & 12 & 8 & 0.73 & 0.01 \\
\hline Truncus & 22 & 8 & 7 & 0.76 & 12 & 8 & 0.59 & 0.04 \\
\hline $\begin{array}{l}\text { Mean } \\
( \pm S D)\end{array}$ & $\begin{array}{l}21^{*} \\
( \pm 2)\end{array}$ & $\begin{array}{l}9 \\
( \pm 2)\end{array}$ & $\begin{array}{l}9 \\
( \pm 2)\end{array}$ & $\begin{array}{l}0.86 \\
( \pm 0.17)\end{array}$ & $\begin{array}{l}13 \\
( \pm 2)\end{array}$ & $\begin{array}{l}8 \\
( \pm 1)\end{array}$ & $\begin{array}{l}0.59 \ddagger \\
( \pm 0.16)\end{array}$ & \\
\hline
\end{tabular}

\begin{tabular}{|c|c|c|c|c|c|c|c|c|}
\hline Diagnosis & $\begin{array}{l}\dot{Q}^{a} \\
\text { (\% of normal) }\end{array}$ & $\begin{array}{l}C P P^{a} \\
(m m H g)\end{array}$ & $\begin{array}{l}C B F V^{a} \\
\left(\mathrm{~cm} \cdot \sec ^{-1}\right)\end{array}$ & $\begin{array}{l}d V / d P^{e} \\
\left(\mathrm{~cm} \cdot \sec ^{-1} \cdot m m H g^{-I}\right)\end{array}$ & $\begin{array}{l}C P P^{b} \\
(m m H g)\end{array}$ & $\begin{array}{l}C B F V^{b} \\
\left(\mathrm{~cm} \cdot \sec ^{-1}\right)\end{array}$ & $\begin{array}{l}d V / d P^{f} \\
\left(\mathrm{~cm} \cdot \sec ^{-1} \cdot \mathrm{mmHg}^{-1}\right)\end{array}$ & $P \S$ \\
\hline \multicolumn{9}{|c|}{ Group $D^{t}$ patients (low-flow CPB; detectable perfusion absent) } \\
\hline DORV & 27 & 8 & 7 & 0.51 & 11 & 15 & 0.81 & 0.01 \\
\hline TGA & 24 & 10 & 8 & 0.34 & 12 & 14 & 0.48 & 0.04 \\
\hline TGA & 18 & 8 & 6 & 1.03 & 9 & 15 & 1.30 & 0.03 \\
\hline AVSD & 22 & 9 & 6 & 0.43 & 9 & 11 & 0.62 & 0.01 \\
\hline Truncus & 29 & 10 & 8 & 0.78 & 11 & 13 & 0.89 & 0.01 \\
\hline VSD & 26 & 11 & 7 & 0.44 & 10 & 10 & 0.57 & 0.02 \\
\hline VSD & 24 & 9 & 9 & 0.67 & 14 & 11 & 0.81 & 0.01 \\
\hline DORV & 24 & 10 & 8 & 0.35 & 10 & 10 & 0.47 & 0.02 \\
\hline AVSD & 31 & 11 & 7 & 0.64 & 10 & 9 & 0.77 & 0.03 \\
\hline TGA & 20 & 8 & 9 & 1.01 & 9 & 11 & 1.13 & 0.02 \\
\hline VSD & 22 & 9 & 6 & 0.54 & 10 & 8 & 0.69 & 0.01 \\
\hline TGA & 23 & 9 & 8. & 0.70 & 10 & 11 & 0.84 & 0.02 \\
\hline $\begin{array}{l}\text { Mean } \\
( \pm S D)\end{array}$ & $\begin{array}{l}24 \\
( \pm 4)\end{array}$ & $\begin{array}{l}9 \\
( \pm 1)\end{array}$ & $\begin{array}{l}7 \\
( \pm 1)\end{array}$ & $\begin{array}{l}0.62 \\
( \pm 0.23)\end{array}$ & $\begin{array}{l}10 \dagger \\
( \pm 1)\end{array}$ & $\begin{array}{l}12 \dagger \\
( \pm 2)\end{array}$ & $\begin{array}{l}0.78 \ddagger \\
( \pm 0.25)\end{array}$ & \\
\hline
\end{tabular}


TABLE II Cardiopulmonary bypass data - continued

\begin{tabular}{|c|c|c|c|c|c|c|c|c|}
\hline Diagnosis & $\begin{array}{l}\dot{Q}^{a} \\
\text { (\% of normal) }\end{array}$ & $\begin{array}{l}C P P^{a} \\
(m m H g)\end{array}$ & $\begin{array}{l}C B F V^{a} \\
\left(\mathrm{~cm} \cdot \sec ^{-1}\right)\end{array}$ & $\begin{array}{l}d V / d P^{e} \\
\left(\mathrm{~cm} \cdot \mathrm{sec}^{-1} \cdot \mathrm{mmHg}^{-1}\right)\end{array}$ & $\begin{array}{l}C P P^{b} \\
(m m H g)\end{array}$ & $\begin{array}{l}C B F V^{b} \\
\left(\mathrm{~cm} \cdot \mathrm{sec}^{-1}\right)\end{array}$ & $\begin{array}{l}d V / d P^{f} \\
\left(\mathrm{~cm} \cdot \mathrm{sec}^{-1} \cdot \mathrm{mmHg}^{-1}\right)\end{array}$ & $P \S$ \\
\hline \multicolumn{9}{|c|}{ Group $D^{2}$ patients (low-flow CPB; detectable perfusion absent) } \\
\hline TGA & 26 & 9 & 6 & 0.89 & 14 & 9 & 0.69 & 0.04 \\
\hline TGA & 19 & 10 & 7 & 1.21 & 13 & 10 & 0.77 & 0.03 \\
\hline VSD & 22 & 8 & 7 & 0.95 & 12 & 8 & 0.78 & 0.01 \\
\hline AVSD & 24 & 11 & 9 & 0.85 & 15 & 9 & 0.71 & 0.02 \\
\hline TGA & 18 & 9 & 8 & 1.03 & 14 & 9 & 0.86 & 0.02 \\
\hline $\begin{array}{l}\text { Mean } \\
( \pm S D)\end{array}$ & $\begin{array}{l}22 \\
( \pm 3)\end{array}$ & $\begin{array}{l}9 \\
( \pm 1)\end{array}$ & $\begin{array}{l}7 \\
( \pm 1)\end{array}$ & $\begin{array}{l}0.99 \\
( \pm 0.14)\end{array}$ & $\begin{array}{l}14 \\
( \pm 1)\end{array}$ & $\begin{array}{l}9 \\
( \pm 1)\end{array}$ & $\begin{array}{l}0.76 \pm \\
( \pm 0.07)\end{array}$ & \\
\hline
\end{tabular}

$* P<0.05$ compared with all other groups.

$\dagger P<0.05$ compared with Groups $C$ and $D^{2}$.

$\ddagger P<0.05$ compared with intragroup value during decreasing $\mathrm{Q}$ and $\mathrm{CPP}$.

$\S P$ values represent comparisons between $d V / d P^{e}$ and $d V / d P^{f}$.

Abbreviations: VSD - ventricular septal defect; TGA - transposition of the great arteries; AVSD - atrioventricular septal defect; DORV - double outlet right ventricle; TAPVD - total anomalous pulmonary venous drainage; Truncus - truncus arteriosus; $\dot{Q}$ - pump flow; CPP - cerebral perfusion pressure; CBFV - cerebral blood flow velocity; $\mathrm{dV} / \mathrm{dP}$ - change in CBFV per mmHg change in CPP; ${ }^{\mathrm{a}}$ - values below which CBFV was no longer detectable during decreasing $\dot{Q}$ and CPP; ${ }^{b}$ - values at which CBFV became detectable during increasing $\dot{Q}$ and $C P P ;{ }^{c}-$ lowest value . reached during decreasing $Q$ and $C P P$ (detectable $C B F V$ always present); ${ }^{d}$ - values during increasing $Q$ and $C P P ;{ }^{e}-$ values during decreasing $\dot{Q}$ and CPP; ${ }^{\prime}$ - values during increasing $Q$ and CPP.

(low-flow CPB) patients (Figure 2) and demonstrated no increase in their AFP. Five patients (Group $D^{2}$ ) demonstrated a pattern similar to that seen in the Group $C$ (PHCA) patients (Figure 3) and demonstrated a transient increase in their AFP. The CPP at which detectable CBFV returned after low-flow CPB was significantly greater in the $D^{2}$ patients when compared with the $D^{1}$ patients but was not significantly different than the Group C (PHCA) patients.

All patients survived their operations and none showed evidence of neurological changes from their preoperative assessments.

\section{Discussion}

The findings of our study demonstrate three distinct patterns of CBFV recovery after decreases in $Q$ during profound hypothermic low-flow CPB and PHCA.

The linear relationship and the lack of difference in $\mathrm{dV} / \mathrm{dP}$ during decreasing and then increasing $\dot{Q}$ and CPP in the Group A (control) patients is in agreement with previously published work. ${ }^{3,11} \mathrm{~A}$ linear relationship between $\mathrm{CBF}$ and $\mathrm{MAP}^{3}$ and $\mathrm{CBFV}$ and $\mathrm{CPP}^{11}$ has been demonstrated during profound hypothermia and suggests a loss of cerebral autoregulation. It is speculated that the observed lack of autoregulation is due to a coldinduced vasoparesis. 3,11 Hysteresis loop behaviour, which is characteristic of elastic vascular tissue and has been suggested to affect vessel diameter at lower CPPs, $5,7,11$ is unlikely to be an important factor at the CPPs induced

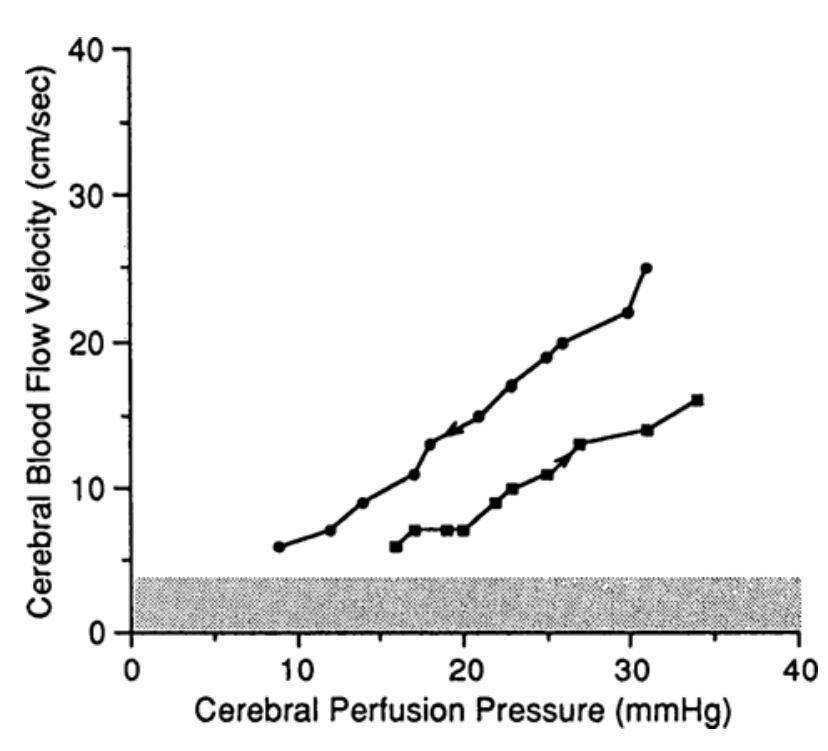

FIGURE 3 Interpolated values of cerebral blood flow velocity (CBFV) changes representing one patient during decreasing ( $-\mathbf{-}$ ) and increasing $(-\mathbb{Q}-$ ) cerebral perfusion pressure (CPP), induced by alterations in pump flow to establish profound hypothermic circulatory arrest (PHCA). The slope (dV/dP) of the CBFV-to-CPP relationship during decreasing $\left(0.92 \mathrm{~cm} \cdot \mathrm{sec}^{-1} \cdot \mathrm{mm} \mathrm{Hg}^{-1}\right)$ and increasing $\left(0.57 \mathrm{~cm} \cdot \mathrm{sec}^{-1} \cdot \mathrm{mmHg}^{-1}\right)$ pump flow respectively were determined by linear regression analysis. The $\mathrm{dV} / \mathrm{dP}$ during decreasing pump flows and $\mathrm{CPP}$ was significantly greater than during increasing pump flows and CPP after PHCA $(P=0.03)$. The shaded area represents the area below the threshold of resolution of the transcranial Doppler $\left(3-4 \mathrm{~cm} \cdot \mathrm{sec}^{-1}\right)$. 
by alterations of $\dot{Q}$ within the normal range of $100-150$ $\mathrm{ml} \cdot \mathrm{kg}^{-1} \cdot \mathrm{min}^{-1}$ in the Group A patients.

In Group B (low-flow CPB) patients the greater $\mathrm{dV}$ / $\mathrm{dP}$ immediately following a period of low-flow CPB has several possible explanations. If the diameter of the MI segment is fixed by bone ${ }^{15}$ changes in vessel diameter producing alterations in the CBFV must occur distally or, alternatively, $\mathrm{CBF}$ must change. The increase in mean CBFV is compatible with an increase in CBF. This appears initially to disagree with the work of Greeley et $a l$. who, using a $\mathrm{Xe}^{131}$ washout technique to determine $\mathrm{CBF}$, demonstrated that at five minutes after return to normal pump flows CBF was no different from that before the low-flow state. Their work differs from the present study in that we used TCD sonography to monitor of cerebral perfusion continuously. In our study the increase in $\mathbf{Q}$ and CPP to normal from low-flow states occurred over a $30 \mathrm{sec}$ to one minute interval and, by five (3.2 $\pm 1.2)$ minutes after the end of the low-flow state, the CBFV had returned to pre low-flow values which is compatible with the results of Greeley et al. ${ }^{3}$ However, these results suggest that a transient period of cerebral vasodilatation may occur. No increase in AFP was demonstrated during this period. This pattern of CBFV recovery is also compatible with the hysteresis properties of elastic tissues $^{5-7}$ but only if the CPP decreased to the extent that the M1 segment begins to collapse away from the walls of its osseous tunnel (i.e., falls below its critical closing pressure).

In the Group $\mathrm{C}$ (PHCA) patients the lower $\mathrm{dV} / \mathrm{dP}$ of the CBFV-to-CPP relationship post-PHCA when compared with the $\mathrm{dV} / \mathrm{dP}$ prior to PHCA has two potential explanations. The first relates to the cerebral metabolic requirement for oxygen $\left(\mathrm{CMRO}_{2}\right)$. It has been previously demonstrated that $\mathrm{CMRO}_{2}$ and $\mathrm{CBF}$ remain reduced during reperfusion following $\mathrm{PHCA} .{ }^{16,17}$ Such a reduction of the CBF would produce a decrease in CBFV measured in the M1 segment of the MCA irrespective of the diameter of the distal resistance vessels. The second potential explanation relates to the consequences of hypoxia on the brain. Reimer et al. showed that brain lactate concentration increases more after PHCA than after low-flow CPB. ${ }^{17}$ Other studies have demonstrated increases in ICP following severe hypoxic episodes in neonates, related to cellular oedema. ${ }^{18} \mathrm{~A}$ transient increase in AFP related to the product of $T \times$ $\mathrm{C}$ has been demonstrated post-PHCA in neonates and infants following PHCA. ${ }^{12}$ Such an increase in AFP may be due to increases in cellular volume which would mechanically decrease transmural pressure, reduce the diameter of the resistance vessels and possibly result in occlusion of some of these vessels, decreasing the $\mathrm{CBF}$ and
CBFV. The second hypothesis is supported by the observation, in this and other studies, ${ }^{10,11}$ that a greater CPP is necessary to re-establish detectable CBFV following a period of PHCA.

In all the Group D patients CBFV became nondetectable although low-flow $\mathrm{CPB}$ was maintained. The recovery pattern of the CBFV in these patients was not consistent. Twelve patients demonstrated the expected pattern seen after low-flow CPB (as demonstrated by the Group B patients), while five patients demonstrated a pattern consistent with the Group $\mathrm{C}$ patients who had undergone PHCA. We postulate that in these latter five cases the CPP decreased below a critical closing pressure such that the cerebral vessels collapsed and $\mathrm{CBF}$ was no longer possible, thus producing a state similar to cerebral PHCA.

The use of low-flow CPB as an alternative to PHCA has been advocated by some investigators as a means to decrease the occurrence of long-term neuropsychiatric dysfunction, ${ }^{19}$ abnormal cerebral metabolism, ${ }^{14,16}$ cerebral perfusion ${ }^{3,4}$ and brain $\mathrm{pH}^{20}$ following PHCA. In theory, low-flow CPB may offer advantages over PHCA by providing an indefinite period of effective cerebral perfusion during hypothermia. This, however, depends entirely on the adequacy of cerebral oxygen delivery. During periods of such low pump flow and low perfusion pressure and the safety of low-flow CPB may be questionable. Watanabe et al. ${ }^{20}$ reported in a study using a dog model that a 60-min period of circulatory arrest was followed by an irreversible decrease in brain $\mathrm{pH}$, oxygen tension and an increase in brain carbon dioxide tension, whereas 120-min of low-flow CPB $\left(25 \mathrm{ml}^{-1} \cdot \mathrm{m}^{-2} \cdot \mathrm{min}^{-1}\right)$ demonstrated recovery in brain $\mathrm{pH}$ and carbon dioxide tension, suggesting that low-flow CPB may offer more cerebral protection than PHCA. However, Rossi et al. ${ }^{21}$ found that creatine kinase-brain isoenzyme, a marker of cerebral ischaemia, increased equally after both PHCA and low-flow CPB, and concluded that there was no benefit to low-flow CPB. One possible explanation for the discrepancies between these two studies is that CPPs may have been lower in the study of Rossi et al., ${ }^{21}$ compromising cerebral perfusion. Unfortunately such values of CPP were not reported. Thus the effectiveness of lowflow $\mathrm{CPB}$ in providing improved cerebral protection remains controversial.

We believe that the determining factor producing the differences seen among these various studies is the CPP and its relation to the critical closing pressure. As long as the CPP is greater than the critical closing pressure, cerebral perfusion is maintained and cerebral protection is adequate. However, if the CPP is less than the critical closing pressure, cerebral perfusion will cease and a cerebral condition will exist similar to PHCA. In the five 
patients who demonstrated a pattern compatible with PHCA a rise in AFP was also noted, coincident with the increase in $\dot{Q}$ and CPP which supports a cerebral non-perfusion state.

The time temperature product has been used previously as an index of ischaemic insult. ${ }^{13,14}$ Its use in this study could be criticized because of the potential for continued cerebral perfusion during the low-flow CPB state. However, since our initial premise was that cerebral perfusion and cerebral oxygen delivery may be limited during lowflow CPB we have used this product to indicate a potential ischaemic insult. The Group C (PHCA) patients demonstrated a greater $\mathrm{T} \times \mathrm{C}$ product than the other groups. This reflects both the use of low-flow CPB for shorter durations than PHCA and the maintenance of a lower NPT possibly due maintenance of continued perfusion with hypothermic blood. In all cases in the Group $\mathrm{C}$ (PHCA) patients the NPT was less than $20^{\circ} \mathrm{C}$ at the commencement of the circulatory arrest period but the patients had warmed somewhat by the end of the circulatory arrest period (Table I). The implications of this finding are that even if cerebral perfusion becomes compromised during the low-flow CPB period and a period of effective cerebral circulatory arrest results, the risk of neurological injury may be less if we accept the $T \times$ $\mathrm{C}$ as an indicator of risk from cerebral ischaemia.

Finally, there are some methodological considerations that merit comment. Mean arterial blood pressure alone is a poor indicator of CPP, ${ }^{22}$ which is defined as MAP minus ICP. The use of ICP to determine CPP offers advantages over the use of CVP during CPB, as the CVP catheter tip ideally lies in the junction of the superior vena cava and the right atrium. In this position it will measure a pressure much lower that of the ICP and more closely related to blood flow back to the pump. ${ }^{12,23} \mathrm{In}-$ tracranial pressure in the infant can be estimated noninvasively, using the Ladd intracranial pressure monitor to obtain a measure of AFP, ${ }^{24}$ which correlates well with ICP in neonates and infants. ${ }^{25}$

In this study TCD was used to measure flow velocity in a single vessel, the middle cerebral artery. This is the largest of the basal cerebral arteries and dominant in regard to flow (70\% of the ipsilateral hemispheric flow). ${ }^{15}$ The basal cerebral arteries originate from the internal carotid syphon. Thus the MCA is a direct continuation of the main branch of the internal carotid artery, coursing in a horizontal plane, laterally and slightly anterior. The M1 or precommunicating segment of the MCA is the initial portion of the MCA and gives rise to numerous lenticulostriate perforators. The TCD technology allows continuous measurement of CBFV in major cranial vessels in a noninvasive, real-time, dynamic manner. ${ }^{4,10,22,26}$ Several assumptions underlying the relationship between
CBFV and CBF have been previously described. ${ }^{27,28}$ Potential problems in the measurement of CBFV are errors based on the physics of sound waves and Doppler instruments. The maximum error that could be attributed to the change observed is related to the angle of insonation and the Doppler resolution. Cadaveric studies have shown that the angle of insonation from the temporal window and the M1 segment of the middle cerebral artery is less than 20 degrees. Since the Doppler shift is proportional to the cosine of this angle, the maximum error generated by this variation in the angle is $7 \%$. The interindividual variability, as measured by the coefficient of variation, was $6 \%$, suggesting that the variability is less than the maximum error due to the angle of insonation. Doppler resolution is determined by the frequency of the transducer (carrier frequency) and the angle of the Doppler beam. As discussed, the angle of insonation was minimal and the Transpect TCD high-pass filters are active from 100 to $150 \mathrm{~Hz}$. This translates into a minimal display velocity of approximately $3-4 \mathrm{~cm} \cdot \mathrm{sec}^{-1}$, "which is considerably below the lowest flow velocity where the middle cerebral artery flow signal abruptly disappears. None the less it is possible that patients in this study may have had cerebral perfusion with no detectable CBFV.

In summary, this study demonstrates that the pattern of CBFV-to-CPP relationships varies with the mode of $\mathrm{CPB}$ management utilized during profound hypothermia. In addition, possible existence of a critical opening pressure during low-flow CPB, similar to that seen after PHCA, raises concerns about potential for cerebral ischaemia during this mode of perfusion. The knowledge of this possibility, together with an increased understanding of the potential of the brain-protective effects of profound hypothermia, may improve the management of infants undergoing corrective cardiac procedures.

\section{Acknowledgments}

We wish to thank Medasonics, Fremont, California for the provision of equipment and assistance in this study, Dr. Ian K. Ehrlich for assistance in data acquisition and Dr. J.E.S. Relton for assistance in preparation of the manuscript.

\section{References}

1 Fox LS, Blackstone RH, Kirklin JW, Bishop SP, Bergdahl $L A, B r a d l e y E L$. Relationship of brain blood flow and oxygen consumption to perfusion flow rate during profoundly hypo-thermic cardiopulmonary bypass. An experimental study. J Thorac Cardiovasc Surg 1984; 87: 658-64.

2 Rebeyka IM, Coles JG, Wilson GJ, et al. The effect of low-flow cardiopulmonary bypass on cerebral function: an 
experimental and clinical study. Ann Thorac Surg 1987; 43 391-6.

3 Greeley WJ, Ungerleider RM, Kern FH, Brusino FG, Smith $L R$, Reves $J G$. Effects of cardiopulmonary bypass on cerebral blood flow in neonates, infants, and children. Circulation 1989; 80 (Suppl 1): 1209-15.

4 Hillier SC, Burrows FA, Bissonnette B, Taylor RH. Cerebral hemodynamics in neonates and infants undergoing cardiopulmonary bypass and profound hypothermic circulatory arrest: assessment by transcranial Doppler sonography. Anesth Analg 1991; 72: 723-8.

5 Remington JW. Hysteresis loop behavior of the aorta and other extensible tissues. Am J Physiol 1955; 180: 83-95.

6 Remington $J W$, Alexander RS. Relation of tissue extensibility to smooth muscle tone. Am J Physiol 1956; 185: 302-8.

7 Remington $J W$. Extensibility behavior and hysteresis phenomena in smooth muscle tissues. In: Remington JW (Ed.). Tissue Elasticity. Washington, D.C.: American Physiological Society, 1957: 138-53.

8 van der Linden $J$, Wesslén $O$, Ekroth $R$, Tydén $H$, von $A h n$ H. Transcranial Doppler-estimated versus thermodilution-estimated cerebral blood flow during cardiac operations: influence of temperature and arterial carbon dioxide tension. J Thorac Cardiovasc Surg 1991; 102 95-102.

9 van der Linden J, Priddy $R$, Ekroth $R$, et al. Cerebral perfusion and metabolism during profound hypothermia in children: a study of middle cerebral artery ultrasonic variables and cerebral extraction of oxygen. J Thorac Cardiovasc Surg 1991; 102: 103-14.

10 Taylor RH, Burrows FA, Bissonnette B. No flow during low-flow cardiopulmonary bypass (letter). J Thorac Cardiovasc Surg 1991; 101: 362-4.

11 Taylor RH, Burrows FA, Bissonnette B. Cerebral pressure-flow velocity relationship during hypothermic cardiopulmonary bypass in neonates and infants. Anesth Analg 1992; 74: 636-42.

12 Stow PJ, Burrows FA, McLeod ME, Coles JG. The effect of cardiopulmonary bypass and profound hypothermic circulatory arrest on anterior fontanel pressure in infants. Can J Anaesth 1987; 34: 450-4.

13 Keenan NK, Taylor MJ, Coles JG, Prieur BJ, Burrows FA. The use of visual evoked potentials in assessing cardiopulmonary bypass and circulatory arrest. Electroencephalogr Clin Neurophysiol 1987; 68: 214-6.

14 Burrows FA, Hillier SC, McLeod ME, Irons KS, Taylor $M J$. Anterior fontanel pressure and visual evoked potentials in neonates and infants undergoing profound hypothermic circulatory arrest. Anesthesiology 1990; 73: 632-6.

15 Carpenter MB, Sutin J. Human Neuroanatomy (8th ed.). Baltimore: Williams \& Wilkins, 1983: 872.

16 Greeley WJ, Kern FH, Ungerleider RM, et al. The effect of hypothermic cardiopulmonary bypass and total circulatory arrest on cerebral metabolism in neonates, infants, and children. J Thorac Cardiovasc Surg 1991; 101: 783-94.

17 Reimer H, Burrows FA, Bissonnette B. Cerebral metabolism during low-flow cardiopulmonary bypass and profound hypothermic circulatory arrest. Anesthesiology 1992; 77: Al135.

18 Lupton BA, Hill A, Roland EH, Whitfield MF, Flodmark $O$. Brain swelling in the asphyxiated term newborn. Pathogenesis and outcome. Pediatrics 1988; 82: 139-46.

19 Ferry $P C$. Neurological sequelae of open-heart surgery in children. An "irritating question." Am J Dis Child 1990; 144: 369-73.

20 Wantanabe $T$, Orita $H$, Kobayashi $M$, Washio $M$. Brain tissue $\mathrm{pH}$, oxygen tension, and carbon dioxide tension in profoundly hypothermic cardiopulmonary bypass. Comparative study of circulatory arrest, nonpulsatile low-flow perfusion, and pulsatile low-flow perfusion. J Thorac Cardiovasc Surg 1989; 97: 396-401.

21 Rossi $R$, Ekroth $R$, Thompson $R J$. No flow or low flow? A study of the ischaemic marker creatine kinase BB after deep hypothermic procedures. J Thorac Cardiovasc Surg 1989; 98: 193-9.

22 Lundar $T$, Lindberg $H$, Lindegaard $K-F$, et al. Cerebral perfusion during major cardiac surgery in children. Pediatr Cardiol 1987; 8: 161-5.

23 Freisen $R H$, Thieme $R$. Changes in fontanel pressure during cardiopulmonary bypass and profound hypothermic circulatory arrest in infants. Anesth Analg 1987; 66: 94-6.

24 Vidyasagar D, Raju TNK. A simple non-invasive technique of measuring intracranial pressure in the newborn. Pediatrics 1977; 59: 957-61.

25 Hill $A$, Volpe JJ. Measurement of intracranial pressure using the Ladd intracranial pressure monitor. J Pediatr 1981; 98: 974-6.

26 Jonas RA, Hickey $P$. Invited letter concerning: No flow during cardiopulmonary bypass. J Thorac Cardiovasc Surg 1991; 101: 364-5.

27 Leon JE, Bissonnette B. Cerebral vascular responses to carbon dioxide in children anaesthetized with halothane and isoflurane. Can J Anaesth 1991; 38: 817-26.

28 Pilato MA, Bissonnette B, Lerman J. Transcranial Doppler: response of cerebral blood flow velocity to carbon dioxide in anaesthetized children. Can J Anaesth 1991; 38: $37-42$. 